\title{
Role of Grazing Intensity on Shaping Arbuscular Mycorrhizal Fungi Communities in Patagonian Semiarid Steppes i $^{2}$
}

\author{
Natalie Dudinszky ${ }^{\text {a,* }}$, M.N. Cabello ${ }^{\text {b }}$, A.A. Grimoldi ${ }^{\text {c,d }}$, S. Schalamuk ${ }^{\text {e }}$, R.A. Golluscio ${ }^{\text {c,d }}$ \\ a Biodiversity and Environmental Research Institute (INIBIOMA)-CONICET, Department of Ecology, National University of Comahue (UNCo)-CRUB, Río Negro, Bariloche, Argentina \\ ${ }^{b}$ Commission of Scientific Research of Buenos Aires Province (CIC), Carlos Spegazzini, Botanical Institute, National University of La Plata (UNLP), La Plata, Buenos Aires, Argentina \\ c Department of Animal Production, School of Agriculture, University of Buenos Aires (UBA), Buenos Aires Argentina \\ ${ }^{\mathrm{d}}$ Agricultural Plant Physiology and Ecology Research Institute (IFEVA)-CONICET, University of Buenos Aires (UBA), Buenos Aires, Argentina \\ e Faculty of Agricultural and Forestry Sciences (FCAyF), National University of La Plata (UNLP), La Plata, Buenos Aires, Argentina.
}

\section{A R T I C L E I N F O}

\section{Article history:}

Received 24 August 2018

Received in revised form 14 February 2019

Accepted 20 February 2019

\section{Key Words:}

arbuscular mycorrhizal fungi

disturbance level

diversity

ecosystem functioning

grazing

life history strategy

\begin{abstract}
A B S T R A C T
Arbuscular mycorrhizal fungi (AMF) are vital for maintaining ecosystem structure and functioning and can be affected by complex interactions between plants and herbivores. Information found in the literature about how ungulate grazing affects AMF is in general contradictory but might be caused by differences in grazing intensities (GIs) among studies. Hence we studied how different GIs affect the composition, diversity, and abundance of AMF communities in a semiarid steppe of Patagonia. We predicted that 1 ) total AMF spore abundance (TSA) and diversity would decrease only under intense-grazing levels and 2) AMF species spore abundance would depend on their life-history strategies and on the GI. To test our predictions, we compared AMF communities among nongrazed (NG), moderately grazed (MG, 0.1-0.3 sheep ha ${ }^{1}$ ), and intensely grazed sites (IG, > 0.3 sheep $\mathrm{ha}^{1}{ }^{1}$. GI was the most important factor driving changes in TSA and diversity, regardless of host plant identity. TSA, diversity, and evenness significantly decreased in IG sites but were not affected by MG. AMF species spore abundance varied depending on their life-history strategies and GI. Families with high growth rates like Glomeraceae and probably Pacisporaceae showed the highest spore abundance in all sites but decreased under IG. Species with higher carbon demands like Gigasporaceae showed low spore abundance and frequency in NG and MG sites and were absent in IG sites. In contrast, species with low growth rates, but efficient carbon usage, like Acaulosporaceae, showed low spore abundance in all sites but increased in IG sites compared with NG or MG sites. We conclude that intensification of grazing reduces AMF diversity and abundance, with the likely loss of AMF benefits for plants, such as improved nutrient and water uptake and soil aggregation. Therefore, sustainable grazing systems should be designed to improve or restore AMF communities, particularly in degraded rangelands, like the Patagonian steppes.
\end{abstract}

@ 2019 The Society for Range Management. Published by Elsevier Inc. All rights reserved.

\section{Introduction}

Complex interactions between plants and herbivores can affect soil microorganisms influencing ecosystem structure and functioning (van der Heijden et al., 1998a, 1998b; van der Heijden and Sanders, 2003) because changes or loss of belowground diversity can significantly reduce plant diversity, decomposition, nutrient retention, and nutrient cycling (Wagg et al., 2014). Particularly, soil

is This study was funded by Fondo Nacional de Ciencia y Tecnología [ANPCyT-FONCyT PICTO 36894, PICT 0463, PICT 608 1512], CICPBA, and by the Universidad de Buenos Aires [UBA-AG 044, UBA-AG 2018].

* Correspondence: Natalie Dudinszky, INIBIOMA-CONICET-UNCOMA, Quintral 1250,

Bariloche, Río Negro 8400, Argentina. Tel.: + 5492944397687.

E-mail address: dudinszky@comahue-conicet.gob.ar (N. Dudinszky). diversity of arbuscular mycorrhizal fungi (AMF) is a major factor contributing to the maintenance of plant biodiversity and, therefore, to ecosystem variability and productivity (van der Heijden et al., 1998a, 1998b; van der Heijden and Sanders, 2003). AMF colonize about two-thirds of land plant species (Treseder and Cross, 2006; Smith and Read, 2008; Brundrett, 2009) developing what is currently considered the most ecologically important symbiosis on the planet (Fitter et al., 2005; van der Heyde et al., 2017).

External hyphae of AMF can grow up to 100 times longer than root hairs, representing a significant contribution to the plant belowground system (Miller et al., 1995). As a result, AMF can enhance host plant (HP) uptake of phosphate (Karandashov and Bucher, 2005; Javot et al., 2007) and nitrogen (both by accelerating decomposition and directly acquiring nitrogen from organic material) (Hodge et al., 2001), water, and micronutrients. In return, up to $20 \%$ of plant photosynthetic carbohydrates are transferred to the fungus (Parniske, 2008; Smith and Read, 
2008). AMF can also play an important role in soil formation (Rillig and Mummey, 2006; Lehmann et al., 2017).

All beneficial effects of AMF are most apparent under conditions of limited nutrient and water availability (Parniske, 2008) and, therefore, are particularly important for plant survival or restoration in arid and semiarid ecosystems or degraded areas (Allen, 1989; Requena et al., 2001; Titus et al., 2002; Rillig and Mummey, 2006; Allen, 2007; Brundrett, 2009). Consequently, there is a growing interest in how AMF are affected, particularly in poorly grazed and degraded lands (Bethlenfalvay and Dakessian, 1984; Lugo et al., 2003; Su and Guo, 2007; Ba et al., 2012; Antoninka et al., 2015; Cavagnaro et al., 2017, 2018; Ambrosino et al., 2018).

Grazing by domestic herbivores is one of the most generalized disturbances in grasslands worldwide that can change ecosystems structure and functioning by affecting plant annual net primary production (ANPP), physiognomy, diversity (Milchunas et al., 1988; Milchunas and Lauenroth, 1993; Ren et al., 2018) and nutrient cycling (Golluscio et al., 2009; McSherry and Ritchie, 2013; Ren et al., 2018). Grazing can alter plant resources allocation to shoot or roots (Milchunas and Lauenroth, 1993), which can affect AMF colonization (Bethlenfalvay and Dakessian, 1984; Miller et al., 1995; Lugo et al., 2003; Barto and Rillig, 2010; van der Heyde et al., 2017; Cavagnaro et al., 2018), spore abundance, and diversity (Eom et al., 2001; Lugo and Cabello, 2002; van der Heyde et al., 2017). Intense grazing can also reduce AMF hyphal length density by reducing soil moisture, increasing bulk density, and decreasing soil organic C and plant-available N (Ren et al., 2018).

Information found in the literature about how grazing affects AMF is in general variable among studies (van der Heyde et al., 2017). In the case of AMF spore abundance, it ranges from a lack of effects, to increases or decreases, depending on the study considered (Eom et al., 2001; Klironomos et al., 2004; Su and Guo, 2007; Ba et al., 2012; Bai et al., 2013; Antoninka et al., 2015; van der Heyde et al., 2017; Ambrosino et al., 2018). Van der Heyde et al. (2017) have suggested that these inconsistencies could be caused by differences in experimental designs among studies and that sporulation might depend on grazing intensity (GI). Supporting this last statement, studies that report lack of effects-or increases-in AMF spore abundance and diversity have usually tested light or moderate GI or defoliation (Ba et al., 2012; van der Heyde et al., 2017; Ambrosino et al., 2018). A moderate removal of aboveground biomass can stimulate root exudations (von Alten et al., 1993; Buee et al., 2000), which could be beneficial for AMF and, thus, spore production (Ba et al., 2012; van der Heyde et al., 2017). On the other hand, studies reporting decreases of AMF spore abundance and diversity have usually tested higher GIs (Su and Guo, 2007; Ba et al., 2012). Decrease in spore abundance has been explained by the carbon limitation hypothesis, which states that intense defoliation can affect plant carbon availability, reducing the $C$ transferred to the AM symbiont, which can compromise resources allocation of the fungus to spore production or root colonization (Wallace, 1987). Thus, there is an increasing indication of the importance of determining the role of GI on shaping mycorrhizal communities in rangeland ecosystems worldwide (Ba et al., 2012; van der Heyde et al., 2017; Ambrosino et al., 2018).

AMF response to disturbances can vary among species and families depending on their life-history strategies and type of disturbance (van der Heyde et al., 2017). The life-history classification system based on the grouping of functional traits, such as Grime's C-S-R (competitor, stress tolerant, ruderal) framework, can help to explain AMF successional dynamics, as well as biodiversity patterns in natural communities (Chagnon et al., 2013). Species from Glomeraceae have been suggested to have a ruderal strategy (sensu Grime, 1977) because of their high growth rates, early production of many asexual spores, high hyphal turnover rates, more efficient hyphal healing, and more efficient germination, both from spores and hyphae (Chagnon et al., 2013). According to these traits, Glomeraceae are in general tolerant to most disturbance types (van der Heyde et al., 2017) and usually are dominant in disturbed ecosystems (Su and Guo, 2007; Ba et al., 2012; Stover et al., 2012; Brundrett and Ashwath, 2013). Gigasporaceae seem to be competitive species and have higher carbon demands, invest more biomass in extraradical hyphae, are favored by high N-to-P environments (Chagnon et al., 2013), germinate preferably or exclusively from spores after a dormancy period (Brundrett et al., 1999), and are intolerant to aboveground disturbances like forestry, agriculture, and herbivory (van der Heyde et al., 2017). Acaulosporaceae species are commonly stress tolerant, as they have lower carbon demands (Gehring and Whitham, 2002) because of their low growth rates and long-lived mycelium (Chagnon et al., 2013) and are particularly tolerant to soil mechanical disturbances (van der Heyde et al., 2017). In the case of Pacisporaceae and Ambisporaceae, ecological and phylogenetic information is still lacking (Oehl et al., 2011), although they seem to be disturbance tolerant (van der Heyde et al., 2017). To our knowledge, information about the specific response of AMF families to different intensities of grazing is still scarce.

If carbon is not a limiting resource (i.e., under moderate defoliation and grazing levels), Glomeraceae species might tolerate grazing better than other families because of their high growth and hyphal turnover rates (Chagnon et al., 2013). AMF are particularly stressed when the carbon supply from their host is consistently low (Chagnon et al., 2013), as can occur when the HPs are intensely defoliated (Wallace, 1987). Under carbon stress conditions, successful AMF may be those that use carbon most efficiently, through the slow production of high-cost, long-lived biomass. Glomeraceae species with high growth rates and, therefore, high carbon demands can be affected if severe defoliation produced by intense grazing affects the resources allocated by the HP to the AMF and, thus, can reduce spore production. Consistent with the expectation of stress tolerance, members of the Acaulosporaceae family are more efficient in C usage than members of the Glomeraceae and Gigasporaceae (Chagnon et al., 2013) and might cope better with the carbon limitation resulting from intense grazing. Gigasporaceae species that have large structures (spores and soil mycelium) and the highest carbon demands may be the least tolerant to carbon stress produced by intense grazing, particularly if soil $\mathrm{N}$ is low (Chagnon et al., 2013). Pacisporaceae species were formerly classified within Glomeraceae because they share many similarities in morphology and traits, such as spore structure and mechanisms of production (Oehl and Sieverding, 2004). Therefore, this family might respond to grazing similarly to Glomeraceae, although this is not very well known yet.

In our study we aimed to assess how GI affects AMF communities in Patagonian semiarid steppes. These ecosystems have been subjected to intense and continuous grazing regimes for more than a century (Aguiar, 2005), which have significantly reduced plant diversity (Perelman et al., 1997), cover, and $\mathrm{N}$ and C soil pools, (Austin and Vivanco, 2006; Golluscio et al., 2009). Intense grazing, together with the limited water availability (Sala et al., 1989; Jobbágy and Sala, 2000) and poor nutrient cycling and microbial activity (Austin et al., 2004), have ultimately favored desertification processes (León and Aguiar, 1985) that affect $>90 \%$ of the area (del Valle et al., 1998; Mazzoni and Vazquez, 2009). The composition of the AMF community and influence of grazing have never been studied in the Patagonian semiarid steppe, despite the potential importance of AMF diversity for restoration of plant communities in this degraded ecosystem.

We conducted a field experiment to evaluate differences in AMF spore abundance and diversity of nongrazed (NG) versus MG and intensively grazed areas. According to Wallace's carbon limitation hypothesis (1987) and Connell's (1978) intermediate disturbance hypothesis, which states that the highest diversity is found under intermediate levels of disturbance, we predicted that:

1) Grazing effects on AMF communities will be different according to the GI: moderate grazing will not reduce AMF spore abundance but will increase diversity, while intense grazing will reduce them. 
2) AMF families will show different responses to GI on the basis of their life history strategies: Glomeraceae and probably Pacisporaceae will tolerate moderate grazing better than the other families, Acaulosporaceae will be more successful under intense grazing conditions, and Gigasporaceae will be the least tolerant to intense grazing.

\section{Methods}

\section{Study Area}

The study was carried out at Río Mayo Experimental Ranch (9 895 ha) of INTA (Instituto Nacional de Tecnología Agropecuaria; in English: National Institute of Agricultural Technology) located in the Chubut province of Argentina ( $\left.45^{\circ} 41^{\prime} \mathrm{S}, 70^{\circ} 16^{\prime} \mathrm{W}\right)$. Mean monthly temperatures range from $15^{\circ} \mathrm{C}$ in January to $1^{\circ} \mathrm{C}$ in July. Long-term mean annual precipitation is $150 \mathrm{~mm}$ (Golluscio et al., 1998), with 70\% falling in autumn and winter, $18 \%$ in spring, and $12 \%$ in summer. Strong westerly winds dominate with mean annual speed values of $15-22 \mathrm{~km} \cdot \mathrm{h}^{-1}$ and low humidity contents. Maximum wind speeds occur from September to January and can reach $>120 \mathrm{~km} \cdot \mathrm{h}^{-1}$. Wind, precipitation, and temperature regimes result in high water deficits during the plant growing season (Paruelo et al., 1998). The sampling areas are representative of the semiarid steppe of the Patagonian Occidental District,

(ca. $12.7 \mathrm{M} \mathrm{ha}$ ), which occupies $30 \%$ of the Patagonian phytogeographical province (León et al., 1998). The vegetation is characterized by relatively plain steppes dominated by perennial tussock grasses (32\% basal cover) and shrubs (15\% basal cover), with 55\% of bare soil (Sala et al., 1989). Annual aboveground net primary production (ANPP) is $560 \mathrm{~kg} \cdot \mathrm{ha}^{-1} \cdot \mathrm{yr}^{-1}$ (Jobbágy and Sala, 2000). Soils are coarsely textured Aridisols with high gravel and pebble content throughout the soil profile (Soriano et al., 1983). The soil profile has an upper sandy texture layer ( $45 \mathrm{~cm}$ deep) with scarce soil organic matter content ( $0.4 \%$ ) followed underneath (from 45 to $60 \mathrm{~cm}$ depth) by a sandy-loam texture layer containing $34.8 \%$ of $\mathrm{CaCO}_{3}$ (Paruelo et al., 1988). Grass roots are concentrated in the upper soil layer until $30 \mathrm{~cm}$ of soil depth (Soriano et al., 1987).

\section{Plant Species Selection}

We evaluated AMF composition and spore density in the rhizosphere soil of the dominant native tussock grasses Pappostipa speciosa (Trin. \& Rupr.) Romasch, Pappostipa humilis (Cav.) Romasch, Poa ligularis Nees ex Steud, and Bromus pictus Hook var. pictus (hereafter referred as B. pictus) (Golluscio et al.1998). According to the palatability for sheep, Poa ligularis and B. pictus are the most intensely selected and consumed grasses, while $P$. humilis is the least preferred one (Somlo et al., 1997). All the selected species show some degree of AMF root colonization in the same study area (Cavagnaro et al., 2017, 2018).

\section{Experimental Design}

In December 2006, five independent sampling areas (each one of ca. $1 \mathrm{ha}$ ) were carefully chosen. Within each area, three sites (each one of ca. 0.33 ha) subjected to different levels of GI were selected: one fenced to exclude large herbivores (NG), another subjected to moderate GI (MG; stocking rate: $0.1-0.3$ sheep ha ${ }^{1}$ ), and another subjected to intense grazing (IG; stocking rate: $>0.3$ sheep ha ${ }^{-1}$ ). The five sampling areas were considered as blocks within a complete randomized block design (as in Golluscio et al., 2009).

The selected sampling areas have similar slope, aspect, topography, and elevation. Hence, the replicates of the different NG sites were not completely comparable because they differed in the time since grazing cessation as follows: 52, 34, 23, 12, and 8 yr. Golluscio et al. (2009) found no significant differences in vegetation composition and cover or soil properties (soil organic matter, carbon and nitrogen soil pools) among these same NG sites and, therefore, it is expected that no major differences will occur in soil microbial properties. However, as van der Heyde et al. (2017) have found an effect of the time of recovery from grazing on AMF communities, this situation was considered in the data analysis to avoid confounding effects and to test for long-term effects of grazing on AMF parameters.

Because sheep selectivity and consumption of the dominant grasses vary according to their palatability (Elissalde et al., 2002), we aimed at determining if the effects on AMF communities were different depending on HP identity. In each of the five NG, MG, and IG replicates, we obtained samples for spore extraction from the rhizosphere soil of each of the four host grasses: P. ligularis (PL), B. pictus (BP), P. speciosa (PS), and P. humilis (PH); and under bare soil patches (BS). Bare soil patches were considered because they represent an important percentage of soil cover (Golluscio et al., 2009) and are colonized underneath by roots from a mix of grass species (Leva et al., 2009). Samples were taken at the same soil depth in the upper soil layer, where the roots of the target grasses are located, and because grazing effects are usually more visible in this soil layer (Bai et al., 2013). Thus, the experimental design comprised five replicates of three GIs (NG, MG, IG) $\times$ five HP identities $(\mathrm{PL}$, $\mathrm{BP}, \mathrm{PS}, \mathrm{PH}, \mathrm{BS})$.

\section{Spore Isolation and Identification}

AMF spores were isolated from samples of $100 \mathrm{~g}$ (dry weight) of soil by using the wet-sieving and decanting method of Gerdemann and Nicolson (1963). Each sample was wet-sieved and then centrifuged in sucrose gradient (Walker et al., 1982). Quantification was carried out on Petri dishes (9-cm diameter) with a gridline of $1 \mathrm{~cm}$ per side, under a stereoscopic microscope at $50 \times$. Ten divisions were counted and related to the total number of spores with the method of McKenney and Lindsey (1987). For taxonomic identification, fungal spores were mounted onto slides with polyvinyl alcohol with or without Melzer reagent (Morton, 1988). Specimens were compared with original species descriptions and reference isolates described by the International Culture Collection of Arbuscular and Vesicular-Arbuscular Mycorrhizal Fungi, http://fungi.invam.wvu.edu/the-fungi/species-descriptions. html. The observation of spores was corroborated with observations of freshly formed AMF spores in trap cultures. AMF species were identified from morphological rather than molecular-rDNA sequences-features because 1) this is the first study on AMF communities in the Patagonian semiarid steppes, with the correspondence between rDNA sequences and spore morphology entirely unknown; and in our view 2) a molecular approach will result in an oversized technique for the first assessment of the general effects of grazing on AMF diversity because of the large amount of genetic variation within single species of AMF and even within a single AMF spore (Landis et al., 2004; Sanders, 2004).

For each combination of GI and plant species composition, AMF diversity was calculated by the Shannon-Wiener diversity index as follows:

$H=-\sum_{i=1}^{k} \ln (p i) p i$

where $p i$ is the proportion of the spores of $i$ AMF species on the spores of all kAMF species. This index integrates the contribution of species richness or number of species ( $S$ ) and evenness (E), $E=H / l n[S]$, to species diversity.

\section{Data Analysis}

All data analyses were performed with the R 3.4.0 free distribution software (R Development Core Team, 2017). We calculated the spore abundance and frequency of AMF species for each GI (NG, MG, and IG) and for each HP identity (PL, BP, PS, PH and BS). Indicator species analyses were performed with the "indicspecies" package of R. We evaluated the strength of association of AMF species or families with a particular GI or HP using the function "multipatt." This analysis 
calculates an extended indicator value by looking for species that are indicators of both individual site groups and combinations of site groups (De Cáceres, 2013). We also used the function "signassoc" to test the association between each AMF species or family with each site (NG, MG, or IG), regardless of whether the indicator value was the highest or not. We used mode $=0$ ( site-based), alternative $=$ two.sided (to identify either positive or negative associations) and report $P$ values after Sidak's correction for multiple testing (Dufréne and Legendre, 1997; De Cáceres, 2013).

We tested the general effects of GI, HP identity, and the two-way interaction GI $\times$ HP on AMF spore abundance, for all spores together (AMF total spore abundance [TSA]), as well as for each one of the different AM fungal families separately, because changes on spore abundance are more evident at this taxonomical level (Chagnon et al., 2013; Ambrosino et al., 2018). We also tested GI, HP, and GI $\times$ HP effects on AMF spore diversity $(H)$, richness $(S)$, and Evenness (E). To test GI, HP, and GI $\times$ HP effects, we built mixed-effects models for each variable analyzed. All the models included the fixed categorical variables: 1) GI with three levels (NG, MG, and IG), 2) HP with five levels (BP, PL, PS, PH and BS), and 3 ) the two-way interaction $\mathrm{GI} \times \mathrm{HP}$.

To evaluate if the NG areas were completely comparable and to test for any effect of the time passed after grazing cessation, we built a mixed-effects model including the fixed categorical variable time of recovery from grazing (TRG) with five levels $(52,34,23,12$, and 8 yr after grazing cessation) and HP identity to test their effect on TSA, $\mathrm{H}$, richness (S), and E. We found no significant effect of TRG or HP among NG sites on any of the dependent variables analyzed (see Section 1 and Table S1; available online at https://doi.org/10.1016/j.rama.2019.02. 007). Therefore, we included NG sites in the main models built for evaluating the effects of GI, as results will not be biased by variances among NG sites.

To test if GI and HP effects on spore abundance varied across families (SAM), we built another mixed-effects model adding family (FAM) as a factor with four levels (Acaulosporaceae, Glomeraceae, Pacisporaceae, and Gigasporaceae). We were unable to test GI or HP effects on Ambisporaceae and Claroideoglomeraceae because of their low spore abundance and frequency.
In every case, to avoid pseudoreplication, and even though sites were similar in topography and slope, block was added as a random variable as it might include effects coming from other noncontrolled environmental variabilities.

The general models formula was Model $=\mathrm{Y} \sim(\mathrm{HP}+\mathrm{GI}+\mathrm{HP} * \mathrm{GI}+1 /$ block). For generalized mixed-effects models we used the "glmer" function, and for general mixed-effects models the "lmer" function from the "Ime4" package (Bates et al., 2015). In the case of TSA, SAM, and S, the errors had a Poisson distribution and, accordingly, a log link function was used (generalized models). In the case of $\mathrm{H}$ and $\mathrm{E}$, normal distributions were used (general models) and, in case of lack of normality, data were log-transformed to fit normality. We tested overdispersion using the "RVAideMemoire" package (Hervé, 2017) and, when present, we corrected it with the addition of an observation-level random effect factor (Harrison, 2014). For mixed-effects models, $C h i^{2}$ values were calculated using the "ANOVA" (analysis of variance) function of the "car" package (Fox and Weisberg, 2011). If significant effects were found, Tukey post-hoc tests were performed using the package "multcomp" (Hothorn et al., 2008). In the case of the analysis by functional groups, post-hoc tests were applied across grazing intensities within families and across families.

\section{Results}

\section{Characterization of AMF Communities}

AMF spores isolated from the soil samples were grouped into 14 different AMF morphospecies belonging to Ambisporaceae, Acaulosporaceae, Gigasporaceae, Pacisporaceae, Claroideoglomeraceae, and Glomeraceae. All AMF morphospecies were identified at genus level and 10 at species level (Table 1). Among the most frequent species, Pacispora scintillans was the most dominant (frequency $=100 \%$ in each of the NG, MG, and IG sites), followed in lower dominance by Glomus sp.1, Glomus sp.2, Funneliformis mosseae, Acaulospora mellea, Ambispora fecundispora, and Claroideoglomus etunicatum (see taxonomy in Table 1).

According to their indicator value (IndVal), Glomus sp.2 was strongly and significantly associated with NG and MG sites (IndVal $=0.73 ; P=$ 0.011), A. mellea was a good indicator of MG and IG sites (IndVal =

Table 1

Characterization of arbuscular mycorrhizal fungi communities.

\begin{tabular}{|c|c|c|c|c|c|c|c|c|c|c|c|c|c|c|c|c|c|c|c|c|}
\hline \multirow[t]{3}{*}{ Order } & \multirow[t]{3}{*}{ Family } & \multirow[t]{3}{*}{ Species } & \multicolumn{6}{|c|}{ NG } & \multicolumn{6}{|c|}{ MG } & \multicolumn{6}{|l|}{ IG } \\
\hline & & & \multicolumn{6}{|c|}{$f(\%)$} & \multicolumn{6}{|c|}{$f(\%)$} & \multicolumn{6}{|c|}{$f(\%)$} \\
\hline & & & BP & PL & PS & PH & BS & $\begin{array}{l}F \\
(\%)\end{array}$ & $\mathrm{BP}$ & PL & PS & $\mathrm{PH}$ & BS & $\begin{array}{l}F \\
(\%)\end{array}$ & $\mathrm{BP}$ & PL & PS & $\mathrm{PH}$ & BS & $\begin{array}{l}F \\
(\%)\end{array}$ \\
\hline Archaeosporales & Ambisporaceae & $\begin{array}{l}\text { Ambispora fecundispora (Schenck et Smith) } \\
\text { Walker }\end{array}$ & & & & & & 0 & 20 & & & 20 & & 40 & 20 & & & 20 & 20 & 60 \\
\hline \multirow[t]{9}{*}{ Diversisporales } & Acaulosporaceae & Acaulospora delicata Walker, Pfeiff. \& Bloss & & 20 & & & & 20 & & & & 20 & & 20 & & & & & & 0 \\
\hline & & A. mellea Spain et Schenck & & & & & & 0 & & 40 & & 20 & 20 & 60 & 40 & & 20 & 40 & 40 & 80 \\
\hline & Gigasporaceae & Gigaspora sp. & & & & 20 & & 20 & & 20 & & & & 20 & & & & & & 0 \\
\hline & & Scutellospora sp1. & 20 & 20 & & & & 40 & & & & & 20 & 20 & & & & & & 0 \\
\hline & & $\begin{array}{l}\text { S. calospora (Nicolson et Gerdemann) Walker } \\
\text { et Sanders }\end{array}$ & & & 20 & & & 20 & & & & & & 0 & & & & & & 0 \\
\hline & & $\begin{array}{l}\text { S. dipapilosa (Walker et koske) Walker et } \\
\text { Sanders }\end{array}$ & & & & & 20 & 20 & & & & 20 & & 20 & & & & & & 0 \\
\hline & & $\begin{array}{l}\text { S. heterogama (Nicolson et Gerd.) Walker et } \\
\text { Sanders }\end{array}$ & & & & & 20 & 20 & & & & & & 0 & & & & & & 0 \\
\hline & Pacisporaceae & $\begin{array}{l}\text { Pacispora scintillans (Rose et Trappe) Sieverd. } \\
\text { et Oehl }\end{array}$ & 40 & 60 & 40 & 20 & 80 & 100 & 20 & 60 & 40 & 80 & 60 & 100 & 20 & 20 & 20 & 40 & 40 & 100 \\
\hline & Claroideoglomeraceae & $\begin{array}{l}\text { Claroideoglomus etunicatum (Becker et } \\
\text { Gerdemann) Walker et Schüßler }\end{array}$ & & & & & & 0 & & 20 & 20 & & 20 & 60 & & & & & & 0 \\
\hline \multirow[t]{4}{*}{ Glomerales } & Glomeraceae & $\begin{array}{l}\text { Funneliformis mosseae (Nicolson et } \\
\text { Gerdemann) Walker et Schüßler }\end{array}$ & & 20 & & & 20 & 40 & 20 & 20 & & & 40 & 60 & & & & & 20 & 20 \\
\hline & & Glomus ambisporum Smith et Schenck & 20 & & & 20 & 20 & 60 & & 20 & & & & 20 & & & & & & 0 \\
\hline & & Glomus sp. 1 & 40 & 40 & 60 & 40 & 40 & 100 & 20 & 60 & 20 & 20 & 60 & 100 & & 20 & 20 & 80 & 40 & 80 \\
\hline & & Glomus sp.2 & 60 & 80 & 40 & 80 & 60 & 100 & 40 & 40 & 60 & 80 & & 80 & & 20 & 20 & 20 & & 60 \\
\hline
\end{tabular}

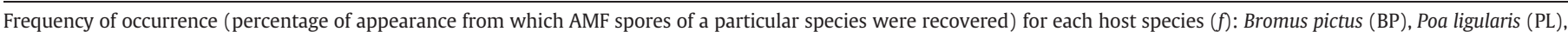
Pappostipa speciosa (PS), P. humilis (PH), and below bare soil patches (BS); and for each grazing intensity (F): nongrazed (NG), moderately grazed (MG), and intensely grazed (IG). 
$0.52 ; P=0.012)$, and $C$. etunicatum tended to be associated with MG sites (IndVal $=0.361 ; P=0.05$ ) (see Table 1$)$. Other associations not mentioned (among GIs or HPs with AMF species or families) were weak and not significant $(P>0.05)$.

Indicator species analyses also showed (best $P$ value, Sidak method) that Acaulosporaceae and A. mellea were least associated with NG sites, G. ambisporum was better associated with NG sites, and Glomus sp.1 was better associated with NG and MG sites while F. mosseae, Glomus sp.2, Glomeraceae, Pacisporaceae, and Gigasporaceae were least associated with IG sites (see detailed $P$ ranks in Table S2; available online at https://doi.org/10.1016/j.rama.2019.02.007).

\section{Grazing Effects on AMF Spore Abundance and Diversity}

GI was the most significant factor affecting AMF TSA, $\mathrm{H}$, and evenness (E) (Table 2). TSA, H, and E were significantly different among NG and IG sites (see Figs. 1a, 2a, c). In IG sites TSA was four times lower (see Fig. 1a) while $\mathrm{H}$ and $\mathrm{E}$ were $50 \%$ lower than in NG sites (see Fig. 2a, c). We found no significant differences among NG and MG sites in terms of AMF TSA (see Fig. 1a), H (see Fig. 2a), or E (see Fig. 2c). AMF richness ( $S$ ) was not significantly affected by GI (see Table 2), being on average low for all areas ( $1.65 \pm 0.64$ S.E.) (see Fig. $2 b$ ).

We found no significant differences in AMF TSA, $\mathrm{H}$, richness ( $\mathrm{S}$ ), or $\mathrm{E}$ among HPs in general or according to each $\mathrm{GI}(\mathrm{GI} \times \mathrm{HP})$ (see Table 2$)$.

\section{Differential Responses of Spore Abundance Among AMF Families and Grazing} Intensities

Spore abundance varied significantly among FAMs and GIs (see Table 2, Fig. $1 \mathrm{~b}-\mathrm{e}$ ). There was a significant interaction in GI x FAM (see Table 2), as spore abundance variance was different in magnitude and significance for each FAM and GI (see Table 2, Fig. 1b-e). Glomeraceae and Pacisporaceae were significantly affected by GI (see Table 2), with three to four times lower spore abundance in IG compared with NG sites (see Fig. 1b and c). For both families, spore abundance did not differ among NG and MG sites (Fig. 1b and c), but Pacisporaceae spore abundance tended to be slightly higher $(P=0.05)$ in MG sites than NG sites (see Fig. 1c). Gigasporaceae and Acaulosporaceae were not significantly affected by GI (see Table 2), but Gigasporaceae was completely absent in IG areas (see Fig. 1e). Acaulosporaceae spore abundance was the only one that did not decrease in IG sites (see Fig. 1d). Glomeraceae and Pacisporaceae showed the highest spore abundance under all GIs except in IG sites, where Acaulosporaceae and Pacisporaceae were similar (see Fig. 1b, e). In NG sites, Glomeraceae spore abundance was higher than Pacisporaceae (Fig. 1b, c). Gigasporaceae showed the lowest spore abundance values among all families in both NG or MG sites (Fig. 1b-e).

Spore abundance of the different families was not significantly affected by HP, and there was not a significant interaction in HP x FAM, indicating that associations among AMF families and HPs were not significant. We were unable to test the three-way interaction among $\mathrm{GI} \times \mathrm{HP} \times \mathrm{FAM}$ because of the characteristics of the data matrix. Claroideoglomeraceae was present only in MG sites with low spore abundance $100 \mathrm{~g} \mathrm{soil}^{-1}$ (0.64 mean \pm 0.36 S.E.), similar to Ambisporaceae, which was present only in MG (0.64 mean \pm 0.41 S.E.) and IG sites ( 0.68 mean \pm 0.39 S.E.)

\section{Discussion}

Grazing intensity exerted the strongest control over AMF spore abundance and diversity in the Patagonian steppes and, as predicted, intense grazing significantly reduced AMF spore abundance and diversity. Intense sheep grazing can significantly reduce aboveground biomass of the HPs (Golluscio et al., 2009). As a consequence, plants could reduce the $C$ translocated to the root system, which can compromise the resources allocated to their AM fungal symbionts and, thus, to AMF spore production (Su and Guo, 2007; Ba et al., 2012). The low levels of AMF spore
Table 2

Statistics summary (mixed-effects models) of the effects of grazing intensity and host plant identity on arbuscular mycorrhizal fungi communities.

\begin{tabular}{|c|c|c|c|c|c|c|c|}
\hline Variable & Factor & $C h i^{2}$ & $P$ & DF & Level & Est & SE \\
\hline \multirow[t]{5}{*}{ TSA } & GI & 30.62 & $<0.001^{* * *}$ & 2 & Intercept-NG & 1.86 & 0.42 \\
\hline & & & & & $\mathrm{MG}$ & 0.32 & 0.56 \\
\hline & & & & & IG & -1.41 & 0.63 \\
\hline & $\mathrm{HP}$ & 4.13 & 0.39 & 4 & & & \\
\hline & $\mathrm{GI} \times \mathrm{HP}$ & 8.54 & 0.38 & 8 & & & \\
\hline \multirow[t]{5}{*}{ H (Diversity) } & GI & 6.04 & 0.04 & 2 & Intercept-NG & 0.35 & 0.12 \\
\hline & & & & & MG & 0.07 & 0.12 \\
\hline & & & & & IG & -0.28 & 0.11 \\
\hline & HP & 7.61 & 0.11 & 4 & & & \\
\hline & $\mathrm{GI} \times \mathrm{HP}$ & 12.12 & 0.14 & 8 & & & \\
\hline \multirow[t]{3}{*}{ S (Richness) } & GI & 3.58 & 0.16 & 2 & & & \\
\hline & $\mathrm{HP}$ & 7.89 & 0.09 & 4 & & & \\
\hline & $\mathrm{GI} \times \mathrm{HP}$ & 6.11 & 0.63 & 8 & & & \\
\hline \multirow[t]{5}{*}{ E (Evenness) } & GI & 8.36 & 0.02 & 2 & Intercept-NG & 0.25 & 0.19 \\
\hline & & & & & MG & 0.14 & 0.26 \\
\hline & & & & & IG & -0.08 & 0.26 \\
\hline & $\mathrm{HP}$ & 6.18 & 0.18 & 4 & & & \\
\hline & $\mathrm{GI} \times \mathrm{HP}$ & 9.78 & 0.28 & 8 & & & \\
\hline \multirow[t]{11}{*}{ SAF } & GI & 11.97 & $0.002^{* *}$ & 2 & Intercept-NG & 3.61 & 1.52 \\
\hline & HP & 10.54 & 0.06 & 4 & & & \\
\hline & FAM & 75.12 & $<0.001^{* * * *}$ & 3 & & & \\
\hline & $\mathrm{GI} \times \mathrm{HP}$ & 10.58 & 0.22 & 8 & & & \\
\hline & $\mathrm{FAM} \times \mathrm{HP}$ & 7.31 & 0.83 & 12 & & & \\
\hline & $\mathrm{GI} \times \mathrm{FAM}$ & 13.31 & $0.038^{*}$ & 6 & $\mathrm{IG} \times \mathrm{GL}$ & -3.81 & 1.27 \\
\hline & & & & & $\mathrm{MG} \times \mathrm{GL}$ & -1.86 & 1.84 \\
\hline & & & & & $\mathrm{IG} \times \mathrm{PA}$ & -3.75 & 1.32 \\
\hline & & & & & $\mathrm{MG} \times \mathrm{PA}$ & -1.24 & 1.26 \\
\hline & & & & & $\mathrm{IG} \times \mathrm{GIG}$ & -2.24 & 2.00 \\
\hline & & & & & $\mathrm{MG} \times \mathrm{GIG}$ & -2.46 & 1.40 \\
\hline \multirow[t]{5}{*}{ Glomeraceae } & GI & 14.01 & $0.016^{*}$ & 2 & Intercept-NG & 1.72 & 0.24 \\
\hline & & & & & MG & -0.54 & 0.35 \\
\hline & & & & & IG & -1.58 & 0.38 \\
\hline & $\mathrm{HP}$ & 9.21 & 0.33 & 4 & & & \\
\hline & $\mathrm{GI} \times \mathrm{HP}$ & 9.89 & 0.18 & 8 & & & \\
\hline \multirow[t]{5}{*}{ Pacisporaceae } & GI & 9.41 & 0.09 & 2 & Intercept-NG & -0.35 & 0.23 \\
\hline & & & & & MG & -0.53 & 0.58 \\
\hline & & & & & IG & -1.27 & 0.53 \\
\hline & $\mathrm{HP}$ & 5.74 & 0.24 & 4 & & & \\
\hline & $\mathrm{GI} \times \mathrm{HP}$ & 4.50 & 0.81 & 8 & & & \\
\hline \multirow[t]{3}{*}{ Acaulosporaceae } & GI & 0.11 & 1.00 & 2 & & & \\
\hline & $\mathrm{HP}$ & 0.26 & 1.00 & 4 & & & \\
\hline & $\mathrm{GI} \times \mathrm{HP}$ & 0.06 & 1.00 & 8 & & & \\
\hline \multirow[t]{3}{*}{ Gigasporaceae } & GI & 0.51 & 0.92 & 2 & & & \\
\hline & $\mathrm{HP}$ & 0.91 & 0.97 & 4 & & & \\
\hline & $\mathrm{GI} \times \mathrm{HP}$ & 0.10 & 1.00 & 8 & & & \\
\hline
\end{tabular}

Chi square $\left(\mathrm{Chi}^{2}\right), P$ values, level of significance $\left({ }^{* * *} 0.001,{ }^{* *} 0.01,{ }^{*}<0.05\right)$, and degrees of freedom (DF) of the effects of grazing intensity (GI), host plant identity (HP), and twoway interaction $\mathrm{HP} \times \mathrm{GI}$ on AMF total spore abundance (TSA), diversity $(\mathrm{H})$, richness (S), evenness (E), spore abundance within each AMF family (Glomeraceae, Pacisporaceae, Acaulosporaceae, and Gigasporaceae), and across AMF families (SAF). SAF also includes the effects of the factor AMF family $(F A M), G I \times F A M$, and $\mathrm{HP} \times$ FAM. Model parameter estimates (Est) $\pm(\mathrm{SE})$ are presented for each factor level (if factor significant). If significant interactions were found, parameter estimates are presented only for the interaction levels. GI levels include intensive grazing (IG) and moderate grazing (MG). FAM levels include Glomeraceae (GL), Pacisporaceae (PAC), and Gigasporaceae (GIG).

abundance and diversity found under intense grazing support these assumptions. AMF diversity did not increase with moderate grazing but was maintained with this type of management. Stimulation of the amount of carbon translocated to the roots by moderate defoliation can benefit AMF (von Alten et al., 1993) and might help explain why AMF spore abundance and diversity did not decrease with moderate grazing (and why Pacisporaceae spore abundance tended to increase). Our results can provide an explanation for the contrasting results found in the literature about the effects of grazing on AMF, confirming that AMF spore community varies with GI, as suggested by other authors (Ba et al., 2012; van der Heyde et al., 2017; Ambrosino et al., 2018).

For each GI, the responses of the different AMF functional groups (families) varied according to their life-history strategies. Glomeraceae and Pacisporaceae were the most dominant families in the entire grazing gradient. Most Glomeraceae species seem to have ruderal strategies 


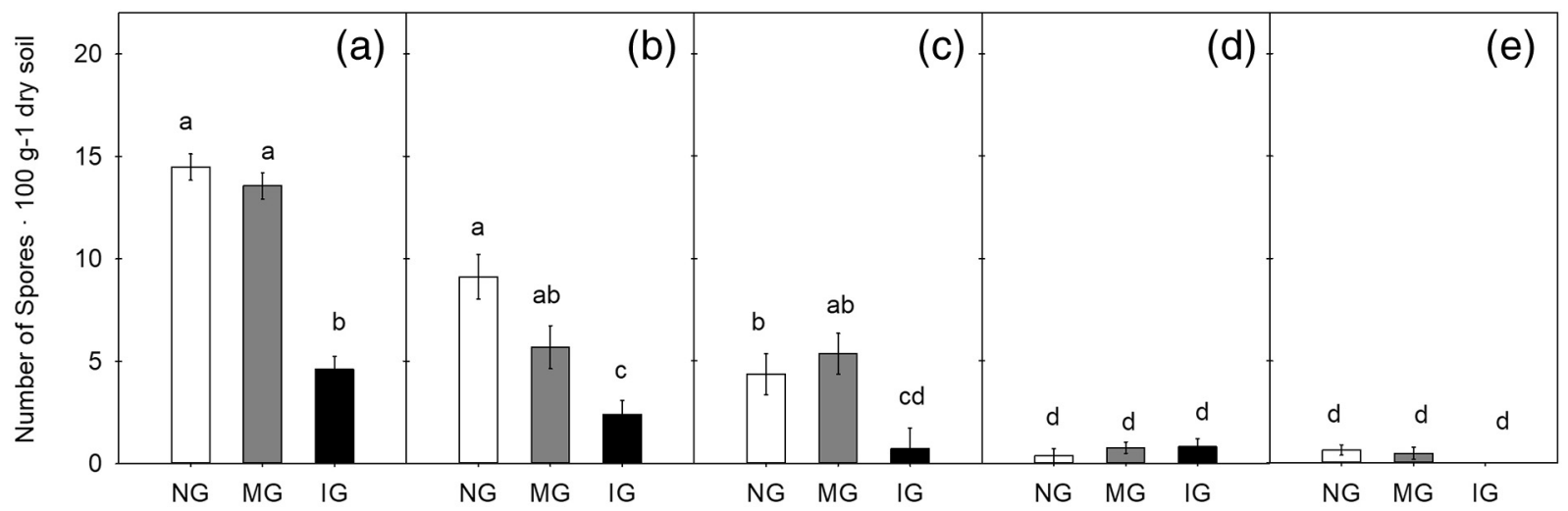

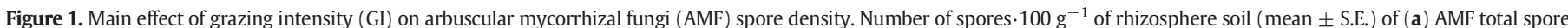

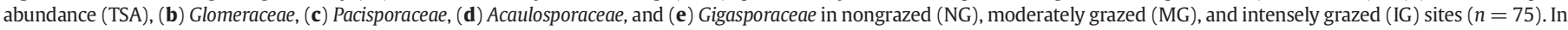

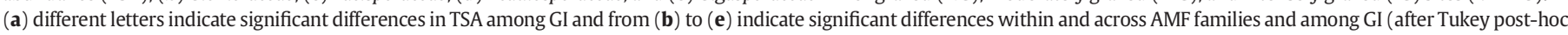
analysis, $P<0.05$ )

(Chagnon et al., 2013), which explain their dominance along disturbed areas (Longo et al., 2016), ranging from steppes (Su and Guo, 2007; Ba et al., 2012), prairies (Stover et al., 2012), and woodlands to wetlands and rainforests (Brundrett and Ashwath, 2013). In the case of

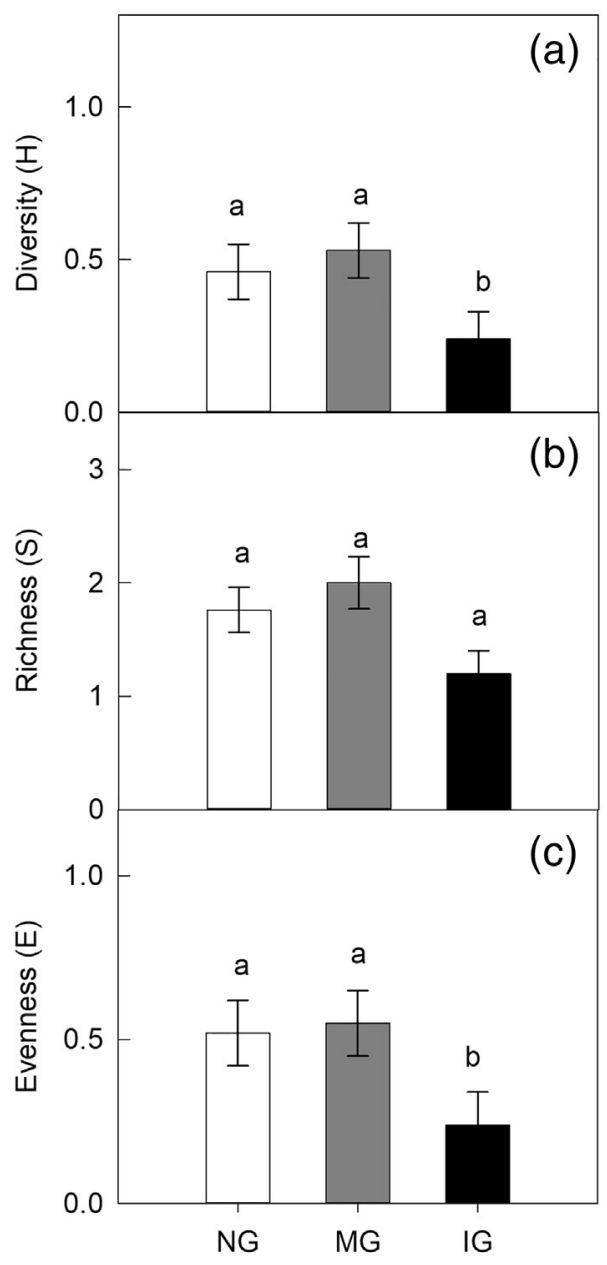

Figure 2. Main effect of grazing intensity (GI) on diversity, richness, and evenness. Arbuscular mycorrhizal fungi (a) Shannon-Wiener diversity index, (b) species richness, and (c) species evenness (mean \pm S.E.) in nongrazed (NG), moderately grazed (MG), and intensely grazed (IG) sites $(n=75)$. Different letters indicate significant differences among GI (after Tukey post-hoc analysis, $P<0.05$ ).
Pacisporaceae, their ecology is not well known yet (Oehl et al., 2011), but the dominance of Pacisporaceae in the entire grazing gradient suggests that this family has adapted to the poor nutrient- and waterdeficient soils of Patagonian steppes. The lack of effects of moderate grazing on Pacisporaceae spore abundance supports the prediction that this family would respond to grazing, similarly to Glomeraceae. The fact that these two families share strong similarities in spore morphology and type of production (Oehl and Sieverding, 2004) might indicate that Pacisporaceae also presents ruderal strategies, which remains to be studied. The reduction of Glomeraceae and Pacisporaceae spore abundance in IG sites supports our prediction that AMF families characterized by fast growth rates and high carbon demands (Chagnon et al., 2013) might be more sensitive to the carbon limitation produced by intense grazing. According to our expectations, Acaulosporaceae, which is in general characterized by low growth rates and, thus, is more efficient to cope with carbon limitation (Chagnon et al., 2013), was more successful under intense grazing than the other families. Gigasporaceae species that have a high carbon demand because of their bigger structures compared with other families and are sensitive to $\mathrm{N}$ limitation (Chagnon et al., 2013) showed a low spore abundance in all sites, probably because of the low N:P ratio of Patagonian steppe soils. This N limitation, together with the carbon limitation produced by severe defoliations, might explain why Gigasporaceae species were completely absent from IG sites. Given the low spore frequency, abundance, and richness of Claroideoglomeraceae and Ambisporaceae, we were unable to determine their response to grazing, but Claroideoglomus etunicatum was a relatively good indicator species of MG sites.

The responses of different AMF FAMs according to their life-history strategies (Chagnon et al., 2013) can help explain the change in spore abundance and diversity in each GI. If intense grazing persists, few species of Glomeraceae, Pacisporaceae, and Acaulosporaceae would dominate-though in low abundance-while Gigasporaceae would tend to disappear from the ecosystem. Considering that Glomeraceae and Pacisporaceae were the most diverse, frequent, and abundant families in NG and MG areas and that intense grazing significantly reduces them, this type of management would imply a significant reduction of AMF diversity in the ecosystem.

The lack of effects of HPs on AMF spore abundance suggests that there is not a strong preference among AMF species and the different host grasses. Also, the fact that in each GI AMF spore abundance was not significantly different among HPs indicates that grazing effects were independent of the sheep preference of the different host grasses studied. These results suggest that grazing effects on AMF symbioses can occur at plant community level. This assumption is supported by the significant reduction of AMF root colonization of both palatable and unpalatable host grasses, which occurs in response to intense 
sheep grazing (Cavagnaro et al., 2018). There is considerable evidence that plants can be linked into common mycorrhizal networks and that $\mathrm{N}, \mathrm{P}$, and $\mathrm{C}$ transfer can occur from one plant to another through AMF hyphae (Johnson et al., 2001; Smith and Read, 2008; Ren et al., 2013). Therefore, intense grazing might have affected the $C$ transfer in the whole mycorrhizal network, independently of any specific effect on the individual host plants.

Our results highlight the importance of the role of GI in shaping AMF communities and the negative consequences that grazing mismanagement can have on the ecosystem. If continuous and intense grazing persist and AMF abundance and diversity is reduced, benefits for plants, such as improved nutrient and water uptake (Hodge et al., 2001; Karandashov and Bucher, 2005; Javot et al., 2007; Parniske, 2008; Smith and Read, 2008) and soil aggregation (Rillig and Mummey, 2006; Lehmann et al., 2017) could be lost. Some functional groups provide particular benefits for their host plants. Glomeraceae can provide better protection of the hosts plants against herbivores, and Gigasporaceae is more efficient in nutrient and water uptake (Chagnon et al., 2013). As intense grazing significantly reduces Glomeraceae abundance and considering that Gigasporaceae are absent under this situation, their particular benefits for the host plants would also be reduced or lost. Exclusion of AMF from the soil could be also relevant because it reduces the rate of organic matter decomposition by reducing the substrate supply to free-living decomposers (Averill et al., 2014), contributing to constrain nutrient cycling. As AMF benefits are particularly important under conditions of limited nutrient and water availability (Parniske, 2008), the loss of AMF abundance and diversity can be critical for ecosystem functioning.

We conclude that maintaining high grazing pressures under continuous regimes will continue to reduce the abundance and diversity of AMF communities, contributing to the ongoing ecosystem degradation of Patagonian steppes.

\section{Implications}

Grazing regime is important to regulate the effect of grazing on plant communities (Zhang et al., 2018), and our results suggest that it would also be key to control the effects on AMF. Our findings indicate that MG could not only improve vegetation cover and soil nutrient content (Golluscio et al., 2009) but also maintain AMF diversity. Other types of adaptive management like seasonal grazing (with inclusion of periodic resting periods) could increase aboveground production of palatable plant species (Golluscio et al., 2015; Zhang et al., 2018), which would probably benefit both herbivores and AMF. Restoration and maintenance of AMF diversity can increase the positive effects on plant diversity and productivity and, consequently, on ecosystem structure and functioning, particularly in degraded rangelands like Patagonian steppes.

\section{Acknowledgments}

We thank the anonymous reviewers for their very valuable and constructive comments during the review process. We thank Guillermo García Martínez, Regina Irueta, and Fernando Cavagnaro for helping with data collection and Ana María R. Montes and Diana Merchant for providing linguistic help. We also thank INTA-EEA Río Mayo, Chubut and Instituto Spegazzini for providing the facilities to accomplish this research. This study was funded by Fondo Nacional de Ciencia y Tecnología [ANPCyT-FONCyT PICTO 36894, PICT 0463, PICT 608 1512], CICPBA and by the Universidad de Buenos Aires [UBA-AG 044, UBA-AG 2018].

\section{Appendix A. Supplementary data}

Supplementary data to this article can be found online at https://doi. org/10.1016/j.rama.2019.02.007.

\section{References}

Aguiar, M.R., 2005. Biodiversity in grasslands. Current changes and future scenarios. In: Reynolds, S.G., Frame, J. (Eds.), Grasslands: developments, opportunities, perspectives. Science Publishers Inc., Enfield, NH, USA, pp. 261-280.

Allen, E.B., 1989. The restoration of disturbed arid landscapes with special reference to mycorrhizal fungi. Journal of Arid Environments 17 (2), 279-286.

Allen, M.F., 2007. Mycorrhizal fungi: highways for water and nutrients in arid soils. Vadose Zone Journal 6, 291-297.

Ambrosino, M.L., Cabello, M.N., Busso, C.A., Velázquez, M.S., Torres, Y.A. Cardillo, D.S Ithurrart, L.S., Montenegro, O.A., Giorgetti, H., Rodriguez, G., 2018. Communities of arbuscular mycorrhizal fungi associated with perennial grasses of different forage quality exposed to defoliation. Journal of Arid Environments 154, 61-69.

Antoninka, A.J., Ritchie, M.E., Johnson, N.C., 2015. The hidden Serengeti-Mycorrhizal fungi respond to environmental gradients. Pedobiologia 58, 165-176.

Austin, A.T., Yahdjian, L., Stark, J.M., Belnap, J., Porporato, A., Norton, U., Ravetta, D.A. Schaeffer, S.M., 2004. Water pulses and biogeochemical cycles in arid and semiarid ecosystems. Oecologia 141, 221-235.

Austin, A.T., Vivanco, L., 2006. Plant litter decomposition in a semi-arid ecosystem controlled by photodegradation. Nature 442, 555-558.

Averill, C., Turner, B.L., Finzi, A.C., 2014. Mycorrhiza-mediated competition between plants and decomposers drives soil carbon storage. Nature 505, 543-545.

Ba, L., Ning, J., Wang, D., Facelli, E., Facelli, J.M., Yang, Y., Zhang, L., 2012. The relationship between the diversity of arbuscular mycorrhizal fungi and grazing in a meadow steppe. Plant and Soil 352, 143-156.

Bai, G., Bao, Y., Du, G., Qi, Y., 2013. Arbuscular mycorrhizal fungi associated with vegetation and soil parameters under rest grazing management in a desert steppe ecosystem. Mycorrhiza 23, 289-301.

Barto, E.K., Rillig, M.C., 2010. Does herbivory really suppress mycorrhiza? A meta-analysis Journal of Ecology 98, 745-753.

Bates, D., Mächler, M., Bolker, B., Walker, S., 2015. Fitting linear mixed-effects models using Ime4. Journal of Statistical Software 67, 51.

Bethlenfalvay, G., Dakessian, S., 1984. Grazing effects on mycorrhizal colonization and floristic composition of the vegetation on a semiarid range in northern Nevada. Journal of Range Management 37, 312-316.

Brundrett, M.C., Abbott, L.K., Jasper, D.A., 1999. Glomalean mycorrhizal fungi from tropical Australia: I. Comparison of the effectiveness and specificity of different isolation procedures. Mycorrhiza 8, 305-314.

Brundrett, M.C., 2009. Mycorrhizal associations and other means of nutrition of vascular plants: understanding the global diversity of host plants by resolving conflicting information and developing reliable means of diagnosis. Plant and Soil 320, 37-77.

Brundrett, M.C., Ashwath, N., 2013. Glomeromycotan mycorrhizal fungi from tropical Australia III. Measuring diversity in natural and disturbed habitats. Plant and Soil 370, 419-433.

Buee, M., Rossignol, M., Jauneau, A., Ranjeva, R., Bécard, G., 2000. The pre-symbiotic growth of arbuscular mycorrhizal fungi is induced by a branching factor partially purified from plant root exudates. Molecular Plant-Microbe Interactions 13, 693-698.

Cavagnaro, R.A., Ripoll, M.P., Godeas, A., Oesterheld, M., Grimoldi, A.A., 2017. Patchiness of grass mycorrhizal colonization in the Patagonian steppe. Journal of Arid Environments 137, 46-49.

Cavagnaro, R.A., Pero, E., Dudinszky, N., Golluscio, R.A., Grimoldi, A.A., 2018. Under pressure from above: overgrazing decreases mycorrhizal colonization of both preferred and unpreferred grasses in the Patagonian steppe. Fungal Ecology Available at: https://doi.org/10.1016/j.funeco.2018.09.003 (in press).

Chagnon, P.L, Bradley, R.L. Maherali, H., Klironomos, J.N., 2013. A trait-based framework to understand life history of mycorrhizal fungi. Trends in Plant Science 18, 484-491.

Connell, J.H., 1978. Diversity in tropical rain forests and coral reefs. Science 199 $1302-1310$

De Cáceres, M., 2013. How to use the indicspecies package (ver. 1.7. 1). R Project 29. Arid Land Research Management 12, 95-121.

De Cáceres, M., 2013. How to use the indicspecies package (ver. 1.7. 1). R Project 29.

del Valle, H.F., Elissalde, N.O., Gagliardini, D.A., Milovich, J., 1998. Status of desertification in the Patagonian region: assessment and mapping from satellite imagery. Arid Land Research Management 12, 95-121.

Elissalde, N., Escobar, J.M., Nakamatsu, V., 2002. Inventario y evaluación de pastizales naturales de la zona árida y semiárida de la Patagonia. INTA, Chubut, Argentina, pp. $1-41$.

Eom, A.H., Wilson, G.W.T., Hartnett, D.C., 2001. Effects of ungulate grazers on arbuscular mycorrhizal symbiosis and fungal community structure in tallgrass prairie. Mycologia 93, 233-242.

Fitter, A.H., Gilligan, C.A., Hollingworth, K., Kleczkowski, A., Twyman, R.M., Pitchford, J.W. 2005. Biodiversity and ecosystem function in soil. Functional Ecology 19, 369-377.

Fox, J., Weisberg, S., 2011. An [R] companion to applied regression. 2nd ed. Sage, Thousand Oaks, CA, USA, p. 449.

Gehring, C.A., Whitham, T.G., 2002. Mycorrhizae-herbivore interactions: population and community consequences. In: van der Heijden, M.G.A., Sanders, I. (Eds.), Mycorrhizal ecology. Springer-Verlag, Berlin, Germany, pp. 295-320.

Gerdemann, J.W., Nicolson, T.H., 1963. Spores of mycorrhizal Endogone species extracted from soil by wet sieving and decanting. Transactions of the British Mycological Society $46,235-244$.

Golluscio, R.A., Sala, O.E., Lauenroth, W.K., 1998. Differential use of large summer rainfal events by shrubs and grasses: a manipulative experiment in the Patagonian steppe. Oecologia $115,17-25$.

Golluscio, R.A., Austin, A.T., García Martínez, G.C., Gonzalez-Polo, M., Sala, O.E., Jackson, R.B., 2009. Sheep grazing decreases organic carbon and nitrogen pools in the Patagonian steppe: combination of direct and indirect effects. Ecosystems 12, 686-697. 
Golluscio, R.A., Bottaro, H.S., Oesterheld, M., 2015. Controls of carrying capacity: degradation, primary production, and forage quality effects in a Patagonian steppe. Rangeland Ecology \& Management 68, 266-275.

Grime, J.P., 1977. Evidence for the existence of three primary strategies in plants and its relevance to ecological and evolutionary theory. American Naturalist 111, 1169-1194.

Harrison, X.A., 2014. Using observation-level random effects to model overdispersion in count data in ecology and evolution. Peer Journal 2, e616.

Hervé, V., 2017. RVAideMemoire: diverse basic statistical and graphical functions. R Packag. 0.9-57.

Hodge, A., Campbell, C.D., Fitter, A.H., 2001. An arbuscular mycorrhizal fungus accelerates decomposition and acquires nitrogen directly from organic material. Nature 413, 297-299.

Hothorn, T., Bretz, F., Westfall, P., 2008. Simultaneous inference in general parametric models. Biometrical Journal 50 (3), 346-363 Available at: https://doi.org/10.1002/ bimj.200810425, Accessed date: 3 January 2018.

Javot, H., Pumplin, N., Harrison, M.J., 2007. Phosphate in the arbuscular mycorrhizal symbiosis: transport properties and regulatory roles. Plant, Cell and Environment 30, 310-322.

Jobbágy, E.G., Sala, O.E., 2000. Controls of grass and shrub aboveground production in the Patagonian steppe. Ecological Applications 10, 541-549.

Johnson, D., Leake, J.R., Read, D.J., 2001. Novel in-growth core system enables functiona studies of grassland mycorrhizal mycelial networks. New Phytologist 152, 555-562.

Karandashov, V., Bucher, M., 2005. Symbiotic phosphate transport in arbuscular mycorrhizas. Trends in Plant Science 10, 22-29.

Klironomos, J.N., McCune, J., Moutoglis, P., 2004. Species of arbuscular mycorrhizal fungi af fect mycorrhizal responses to simulated herbivory. Applied Soil Ecology 26, 133-141.

Landis, F.C. Gargas, A., Givnish, TJ. 2004. Relationships among arbuscular mycorrhiza fungi, vascular plants and environmental conditions in oak savannas. New Phytologist 164, 493-504.

Lehmann, A., Leifheit, E.F., Rillig, M.C., 2017. Mycorrhizas and soil aggregation. In: Collins Johnson, N., Gehring, C., Jansa, J. (Eds.), Mycorrhizal mediation of soil: C storage. Elsevier, Amsterdam, The Netherlands, pp. 241-262.

León, R.J.C., Aguiar, M.R., 1985. Sheep grazing causes important disturbances in western Patagonian semi-arid grasslands. Phytocoenologia 13, 181-196.

León, R.J.C., Bran, D., Collantes, M., Paruelo, J.M., Soriano, A., 1998. Grandes unidades de vegetación de la Patagonia extra andina. Ecology in Australia 8, 125-144.

Leva, P.E., Aguiar, M.R., Oesterheld, M., 2009. Underground ecology in a Patagonian steppe: root traits permit identification of graminoid species and classification into functional types. Journal of Arid Environments 73, 428-434.

Longo, S., Cofré, N., Soteras, F., Grilli, G., Lugo, M., Urcelay, C., 2016. Taxonomic and functional response of arbuscular mycorrhizal fungi to land use change in central Argentina. In: Pagano, M. (Ed.), Recent advances on mycorrhizal fungi. Springer, Berlin, Germany, pp. 81-91.

Lugo, M.A., Cabello, M.N., 2002. Native arbuscular mycorrhizal fungi (AMF) from mountain grassland (Córdoba, Argentina) I. Seasonal variation of fungal spore diversity. Mycologia 94, 579-586.

Lugo, M.A., González Maza, M.E., Cabello, M.N., 2003. Arbuscular mycorrhizal fungi in a mountain grassland II: seasonal variation of colonization studied, along with its relation to grazing and metabolic host type. Mycologia 95, 407-415.

Mazzoni, E., Vazquez, M., 2009. Desertification in Patagonia. In: Latrubesse, E.M. (Ed.), Natural hazards and human-exacerbated disasters in Latin America. Elsevier Science, Amsterdam, The Netherlands, pp. 351-377.

McKenney, M.C., Lindsey, D.L., 1987. Improved method for quantifying endomycorrhizal fungi spores from soil. Mycologia 79, 779-782.

McSherry, M.E., Ritchie, M.E., 2013. Effects of grazing on grassland soil carbon: a global review. Global Change Biology 19, 1347-1357.

Milchunas, D.G., Sala, O.E., Lauenroth, W.K., 1988. A generalized model of the effects of grazing by large herbivores on grassland community structure. American Naturalist 132, 87-106.

Milchunas, D.G., Lauenroth, W.K., 1993. Quantitative effects of grazing on vegetation and soils over a global range of environments. Ecological Monographs 63, 327-366.

Miller, R., Reinhardt, D., Jastrow, J., 1995. External hyphal production of vesicular arbuscular mycorrhizal fungi in pasture and tallgrass prairie communities. Oecologia 103, 17-23.

Morton, J.B., 1988. Taxonomy of VA mycorrhizal fungi: classification, nomenclature, and identification. Mycotaxon 32, 267-324.

Oehl, F., Sieverding, E., 2004. Pacispora, a new vesicular arbuscular mycorrhizal fungal genus in the Glomeromycetes. Journal of Applied Botany and Food Quality 78, 72-82.

Oehl, F., Alves a Silva, G., Goto, B.T., Costa Maia, L., Sieverding, E., 2011. Glomeromycota: two new classes and a new order. Mycotaxon 116, 365-379.

Parniske, M., 2008. Arbuscular mycorrhiza: The mother of plant root endosymbioses. Nature Reviews Microbiology 6, 763-775.
Paruelo, J.M., Aguiar, M.R., Golluscio, R.A., 1988. Soil water availability in the Patagonian arid steppe: gravel content effect. Arid Soil Research and Rehabilitation 2, 67-74.

Paruelo, J.M., Beltrán, A., Jobbágy, E., Sala, O.E., Golluscio, R.A., 1998. The climate of Patagonia: general patterns and controls on biotic processes. Ecology in Australia 8, 85-101.

Perelman, S.B., León, R.J.C., Bussacca, J.P., 1997. Floristic changes related to grazing intensity in a Patagonian shrub steppe. Ecography 20, 400-406.

R Development Core Team, 2017. R: a language and environment for statistical computing. R Foundation for Statistical Computing, Vienna, Austria.

Ren, L., Lou, Y., Zhang, N., Zhu, X., Hao, W., Sun, S., Shen, Q., Xu, G., 2013. Role of arbuscular mycorrhizal network in carbon and phosphorus transfer between plants. Biology and Fertility of Soils 49, 3-11.

Ren, H., Gui, W., Bai, Y., Stein, C., Rodrigues, J.L.M., Wilson, G.W.T., Cobb, A.B., Zhang, Y., Yang, G., 2018. Long-term effects of grazing and topography on extra-radical hyphae of arbuscular mycorrhizal fungi in semi-arid grasslands. Mycorrhiza 28, 117-127.

Requena, N., Perez-Solis, E., Azcón-Aguilar, C., Jeffries, P., Barea, J.M., 2001. Management of indigenous plant-microbe symbioses aids restoration of desertified ecosystems. Applied and Environmental Microbiology 67, 495-498.

Rillig, M.C., Mummey, D.L., 2006. Mycorrhizas and soil structure. New Phytologist 171, $41-53$

Sala, O.E., Golluscio, R.A., Lauenroth, W.K., Soriano, A., 1989. Resource partitioning between shrubs and grasses in the Patagonian steppe. Oecologia 81, 501-505.

Sanders, I.R., 2004. Plant and arbuscular mycorrhizal fungal diversity-are we looking at the relevant levels of diversity and are we using the right techniques? New Phytologist 164, 415-418.

Smith, S.E., Read, D., 2008. Section I: Arbuscular mycorrhizas. In: Mycorrhizal symbiosis, 3rd ed. Elsevier, London, UK, pp. 11-187.

Somlo, R., Bonvissuto, G., Schlichter, T., Laclau, P., Peri, P., Alloggia, M., 1997. Silvopastora use of Argentine Patagonian forests. In: Gordon, A.M. Newman, S.M. (Eds.), Temperate agroforestry systems. CAB International, Wallingford, UK, pp. 237-250.

Soriano, A., Movía, C.P., León, R.J., 1983. Desert and semidesert of Patagonia. In: West, N.E. (Ed.), Temperate desert and semideserts. Elsevier Scientific Pub. Co., Amsterdam, The Netherlands, pp. 423-457.

Soriano, A., Golluscio, R.A., Satorre, E., 1987. Spatial heterogeneity of the root system of grasses in the Patagonian arid steppe. Bulletin of the Torrey Botanical Club 114 103-108.

Stover, H.J., Thorn, R.G., Bowles, J.M., Bernards, M.A., Jacobs, C.R., 2012. Arbuscular mycorrhizal fungi and vascular plant species abundance and community structure in tallgrass prairies with varying agricultural disturbance histories. Applied Soil Ecology $60,61-70$

Su, Y.Y., Guo, L.D., 2007. Arbuscular mycorrhizal fungi in non-grazed, restored and overgrazed grassland in the Inner Mongolia steppe. Mycorrhiza 17, 689-693.

Titus, J.H., Titus, P.J., Nowak, R.S., Smith, S.D., 2002. Arbuscular mycorrhizae of Mojave Desert plants. Western North American Naturalist 62, 327-334.

Treseder, K.K., Cross, A., 2006. Global distributions of arbuscular mycorrhizal fungi. Ecosystems 9, 305-316.

van der Heijden, M.G.A., Boller, T., Wiemken, A., Sanders, I.R., 1998a. Different arbuscular mycorrhizal fungal species are potential determinants of plant community. Ecology 79, 2082-2091

van der Heijden, M.G.A., Klironomos, J.N., Ursic, M., Moutoglis, P., Streitwolf-Engel, R. Boller, T., Wiemken, A., Sanders, I.R., 1998b. Mycorrhizal fungal diversity determines plant biodiversity, ecosystem variability and productivity. Nature 396, 69-72.

van der Heijden, M.G.A., Sanders, I.R., 2003. Mycorrhizal ecology. Springer, Berlin Heidelberg, Germany, p. 471.

van der Heyde, M., Ohsowski, B., Abbott, L.K., Hart, M., 2017. Arbuscular mycorrhizal fungus responses to disturbance are context-dependent. Mycorrhiza 27, 431-440.

van der Heyde, M., Bennett, J.A., Pither, J., Hart, M., 2017. Longterm effects of grazing on arbuscular mycorrhizal fungi. Agriculture, Ecosystems and Environment 243, 27-33.

von Alten, H., Lindemann, A., Schönbeck, F., 1993. Stimulation of vesicular-arbuscular mycorrhiza by fungicides or rhizosphere bacteria. Mycorrhiza 2, 167-173.

Wagg, C., Bender, S.F., Widmer, F., van der Heijden, M.G.A., 2014. Soil biodiversity and soil community composition determine ecosystem multifunctionality. Proceedings of the National Academy of Science 111, 5266-5270.

Walker, C., Mize, C.W., McNabb Jr., H.S., 1982. Populations of endogonaceous fungi at two locations in central Iowa. Canadian Journal of Botany 60, 2518-2529.

Wallace, L.L., 1987. Mycorrhizas in grasslands: interactions of ungulates, fungi and drought. New Phytologist 105, 619-632.

Zhang, C., Dong, Q., Chu, H., Shi, J., Li, S., Wang, Y., Yang, X., 2018. Grassland community composition response to grazing intensity under different grazing regimes. Rangeland Ecology \& Management 71, 196-204. 